\title{
Methods for calculating the balance during the period of draw-off, drainage of sludge collector cells and construction of secondary embankment dams
}

\author{
Khamidkhon Fayziev ${ }^{1,2}$, Takhirjon Sultanov ${ }^{2 *}$, and Elyor Toshmatov ${ }^{2}$ \\ ${ }^{1}$ Tashkent Institute of Architecture and Civil Engineering, Tashkent, Uzbekistan \\ ${ }^{2}$ Tashkent Institute of Irrigation and Agricultural Mechanization Engineers, Tashkent, Uzbekistan
}

\begin{abstract}
An industrial waste-phosphogypsum-is formed in the production of phosphorus mineral fertilizers. As is well-known, the issues of processing and utilization of phosphogypsum on an industrial scale remain unsolved. Consequently, production waste generated at chemical plants is stored in various types of storage tanks. The currently used hydraulic storage method provides for the supply of waste in the form of a slurry into the hydraulic dump cells, their sequential dehydration in the dump, and the subsequent development of a part of the stored waste for the construction of secondary dams. However, due to the low water-release properties of phosphogypsum, it is impossible to ensure its dehydration to the required degree, in large volumes, and the required period. Therefore, various designs of watertight diaphragms and drainage devices are provided in the sludge collector to accelerate the process of dehydration of the phosphogypsum strata. The balance of the sludge collector should be assessed in two periods: the initial period when the sludge collector cells are filled, bounded by the primary dam, and the subsequent period when the reservoir is built up by erecting secondary dams from the stored material. In the initial period, the operating mode of the sludge collector is divided into two stages: in the first stage, a pond is formed above the layer of sludge with a certain predetermined depth; in the second stage, this depth of water in the pond is kept constant by the spillways. The second build-up period is preceded by a period of cell preparation, namely: the draw-off of the pond and drainage of the cell to a moisture content suitable for the dam filling and normal operation of the mechanisms used in the construction of dams. This article presents the results of filtration studies in sludge collectors with an impermeable screen (made of polymer film, asphalt-polymer concrete, etc.) above the screen drainage system. The calculating methods for the determination of filtration parameters in the second period of operation are described: when the pulp supply stops, and a pond of clarified water with a depth of $\mathrm{H}_{0}$ is drawn off.
\end{abstract}

\section{Introduction}

An industrial waste-phosphogypsum-is formed in the production of phosphorus mineral fertilizers [1, 2]. As is well-known, the issues of processing and utilization of

\footnotetext{
*Corresponding author: takhirjon_sultanov@tiiame.uz,
} 
phosphogypsum on an industrial scale remain unsolved. Consequently, production waste generated at chemical plants is stored in various types of storage tanks.

At present, the most promising method of removing and storing phosphogypsum is hydrostorage [3-9]. This storage method provides for the supply of waste in the form of pulp into the hydraulic dump cells, their sequential dehydration in the dump, and the subsequent development of a part of the stored waste for the construction of secondary dams.

In the initial period, the sludge collector is operated as a bulk storage, i.e., the pulp is fed into the tank, limited by the primary dam.

The balance of the sludge collector should be assessed in two periods: the initial period when the sludge collector cells are filled, bounded by the primary dam, and the subsequent period when the reservoir is built up by erecting secondary dams from the stored material.

In the initial period, the operating mode of the hydraulic dump is divided into two stages: in the first, a pond is formed above the sludge layer with a certain predetermined depth; in the second, this depth of water in the pond is kept constant by the spillways.

The second build-up period is preceded by a period of cell preparation, namely: the draw-off of the pond and drainage of the cell to a moisture content suitable for the dam filling and normal operation of the mechanisms used in the construction of dams.

The methods for calculating filtration in sludge storage dams erected by a fill-in method and located on a natural foundation were developed by N.N. Verigin [10], V.P. Nedrigoy [11], P.E. Kochina [12], and some other researchers [13-18].

The authors of this article have previously developed methods for calculating filtration parameters in a sludge collector in the first period [12]. This article discusses the method for determining the filtration parameters in the second period for a storage tank with a watertight screen (made of polymer film, asphalt-polymer concrete, etc.) above the screen drainage system (Figure 1).

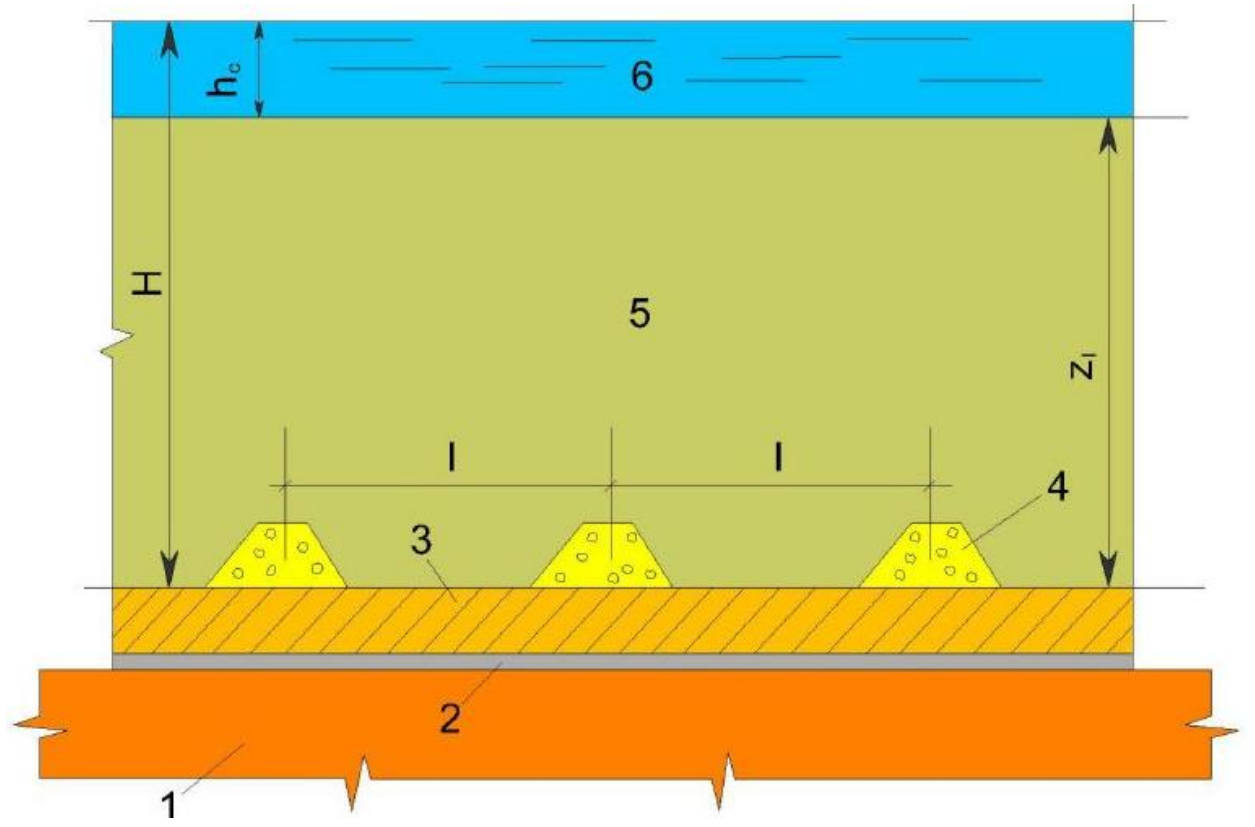

Fig. 1. Filtration scheme in the sludge pond. 1 is base; 2 is film; 3 is protective layer; 4 is belt drainage above the screen; 5 are deposits of phosphogypsum; 6 is pond. 


\section{Methods}

When the capacity of the primary embankment dam is exhausted, the pulp supply stops, and a pond of clarified water with a depth of $\mathrm{H}_{0}$ is drawn off. Then the free moisture front descends to the reservoir drainage system.

To determine the rate and duration of the pond draw-off, the values of filtration losses into the base of the storage tank, and the drainage capacity of the drainage system, we will proceed from the following equations:

$$
\begin{gathered}
q=\frac{d h_{0}}{d t}+q_{f}+\varepsilon, \quad \varepsilon=\varepsilon_{e v}-\varepsilon_{s e t} \\
q_{f}=k_{1} \frac{h_{0}(t)+z_{0}}{z_{0}}
\end{gathered}
$$

where $\mathrm{q}_{\mathrm{f}}$ is the specific flow rate for filtration per $1 \mathrm{~m}^{2}$ of the cell area, $\mathrm{m} /$ day;

$\varepsilon_{\text {ev }}$ is evaporation, $\mathrm{m} /$ day;

$\varepsilon_{\text {set }}$ is settlement, $\mathrm{m} /$ day;

$\mathrm{q}$ is specific consumption of pulp, $\mathrm{m} /$ day;

$\mathrm{q}_{0}$ is specific value of the draw-off of the clarified liquid, $\mathrm{m} /$ day;

$\mathrm{K}_{1}$ is coefficient of filtration of phosphogypsum, $\mathrm{m} /$ day;

$\mathrm{h}_{0}$ is depth of the pond;

$\mathrm{z}_{0}$ is thickness of the protective layer.

Here, $q=0, \quad z_{1}=$ const $=z_{0}$

Substituting equation (2) into (1), we have the following differential equation

$$
\frac{d h_{0}}{d t}=-\frac{k_{1} h_{0}+z_{0}\left(\varepsilon+k_{1}\right)}{z_{0}}
$$

under initial conditions $\mathrm{t}=0, \mathrm{~h}_{0}=\mathrm{H}_{0}$ it has the following solution

$$
h_{0}(t)=\left(H_{0}+A\right) \operatorname{ex\rho }\left(-\frac{k_{1} t}{z_{0}}\right)-A, A=z_{0} \frac{k_{1}+\varepsilon}{k_{1}}
$$

From this solution, at $\mathrm{h}_{0}=0$, we find the duration of the pond draw-off, i.e.

$$
t_{d r}=\frac{z_{0}}{k_{1}} \ln \left(1+\frac{H_{0}}{A}\right)
$$

Considering solution (4), the dependence for the specific value of filtration losses $q_{f}(\mathrm{t})$ is:

$$
q_{f}(t)=\frac{k_{1}}{z_{0}}\left(H_{0}+A\right) \exp \left(-\frac{k_{1}}{z_{0}} t\right)-\frac{\varepsilon}{k_{1}}
$$

To determine the flow rate crossed by the drainage system, which consists of a system of parallel belt drains, we apply the MPSSS method used in calculating the balance of the sludge reservoir during its filling [19-23]. We assume that water enters the drain from a 
water-saturated layer of some thickness $Z_{1}$ with a filtration coefficient and a water loss coefficient $\mu_{\mathrm{f}}$.

Then the flow rate entering I running meter of drains over time is

$$
q_{\sigma p} d t=\frac{k_{1} z_{0}^{2}}{2 \ell} d t=\frac{\mu_{f}}{3} z_{0} d \ell+\ell q_{f} d t, \quad q_{f}(t)=k_{1} \frac{h_{0}+z_{0}}{z_{0}}
$$

We write equation (7) in the form

$$
\frac{2 \ell d \ell}{\ell^{2}-\frac{k_{1} z_{0}^{2}}{2 q_{f}}}=\frac{6 q_{f}}{\mu_{f} z_{1}}
$$

Under initial conditions $t=0, \ell=0$, this equation has a solution of the form

$$
\ell=z_{0} \sqrt{\frac{k_{1}}{2 q_{f}}\left[1-\exp \left(-\frac{6 q_{f} t}{\mu_{f} z_{0}}\right)\right]}
$$

Substituting this solution into equation 7), we determine

$$
2 q_{\sigma \rho(f)}=z_{0} \sqrt{2 k_{1} q_{f}}\left[1-\exp \left(-\frac{6 q_{f} t}{\mu_{f} z_{0}}\right)\right]^{-\frac{1}{2}}
$$

The total flow rate for the entire length of the drain is

$$
Q_{\sigma \rho(f)}=2 q_{\sigma \rho(f)} \cdot L
$$

and for $n$ lines of belt drainage - $\mathrm{nQ}_{\sigma \mathrm{p}(\mathrm{f})}$

To determine the amount of fluid removed from a sand layer with a thickness of $\mathrm{m}=0.3$ $\mathrm{m}$, with the filtration coefficient, $\mathrm{K}_{0}$, and the fluid loss coefficient $\mu_{\mathrm{n}}$, we compose the following balance equation

$$
q_{\sigma p} d t=\frac{k_{1} m^{2}}{2 \ell} d t=\frac{\mu_{n}}{3} m d \ell+\ell q_{f} d t, \quad q_{f}=k_{1} \frac{h_{0}+z_{0}}{z_{0}}
$$

This equation is similar to equation (7) and has a solution of the following form

$$
\ell=m \sqrt{\frac{k_{0}}{2 q_{f}}\left[1-\exp \left(-\frac{6 q_{f} t}{\mu_{n} m}\right)\right]}
$$

Substituting solution (13) into equation (12), we find the value of half of the flow rate into the drain per I running meter.

$$
2 q_{\sigma \rho(n)}=m q_{f}\left[1-\exp \left(-\frac{6 q_{f} t}{\mu_{n} m}\right)\right]^{-\frac{1}{2}}
$$


The flow rate for the entire length of the drain is

$$
Q_{\sigma \rho(n)}=2 q_{\partial \rho(n)} \cdot L
$$

The total flow rate from the layer of phosphogypsum and the layer of sand from drainage lines are

$$
\left.Q_{\sigma p}=2 \mid q_{\sigma p(f)}+q_{\sigma p(n)}\right\rfloor L \cdot n
$$

and the specific flow rate of drainage water is

$$
q_{\sigma p}=\frac{Q_{\sigma p}}{S_{i}}
$$

where $\mathrm{S}_{\mathrm{i}}$ is the area of the corresponding sludge collector cell.

The value of $S_{i}$ for a plain sludge tank can be determined based on the volume of the storage tank $\mathrm{V}_{\mathrm{i}}$ with a height of $\mathrm{Z}_{1}$. We reduce the entire tank to an equal-sized parallelepiped with the same height, and the value is determined as the following ratio

$$
S_{i}=\frac{V_{i}}{Z_{i}}
$$

After the draw-off of the water pond, the rate of dehydration of the phosphogypsum strata should be estimated. If we proceed from the one-dimensional filtration equation for the free moisture front moving under the action of gravity, then

$$
q_{f}=\mu_{f} \cdot \frac{d z_{1}}{d t}=k_{1}
$$

From this equation, we have

$$
z_{1}=\frac{k_{1}}{\mu_{f}} t, \quad t_{t o t}=\frac{z_{1} \mu_{f}}{k_{1}}
$$

$t_{\text {tot }}$ is the duration of the flow of the free moisture front (dehydration) to the base of the storage. However, not all of the filtered flow is removed by the drainage system. To determine the discharge into the drain during the period of draining the stratum of watersaturated phosphogypsum, we compose the following balance equation

$$
q_{\sigma p(f)} d t=\frac{k_{1} z_{1}^{2}}{2 \ell} d t=\frac{\mu_{f} z_{1}}{3} d \ell
$$

Let us substitute dependence (20) into this equation. The resulting equation is

$$
2 \ell d \ell=\frac{3 k_{1} t}{\mu_{f}^{2}} t
$$

We have a solution of the form

$$
\ell=\sqrt{\frac{2}{3}} \frac{k_{1}}{\mu_{f}} t=1.225 \frac{k_{1} t}{\mu_{f}}
$$


Considering this solution, from (21), we obtain the value of half of the flow rate per 1 running meter of the drains.

$$
q_{\sigma \rho(f)}=\frac{k_{1}^{2} t}{\sqrt{6} \mu_{f}}
$$

For the whole length of the drain

$$
Q_{\sigma \rho(f)}=2 q_{\sigma \rho(f)} \cdot L=\sqrt{\frac{2}{3}} \frac{k_{1}^{2} t}{\mu_{f}} L
$$

Let us determine the duration of the flow of the free moisture front in the sand layer from a ratio $[24,25]$ similar to $(20)$ :

$$
t=\frac{m \mu_{n}}{k_{0}}
$$

To determine the flow rate of drainage of the sand layer, consider the following equation

$$
q_{\sigma p(n)} d t=\frac{k_{0} m^{2}}{2 \ell} d t=\frac{\mu_{n} m}{3} d \ell+\ell q_{f} d t, q_{f}=k_{1}
$$

Let us determine the value of the radius of influence of the drain

$$
\ell=m \sqrt{2 k_{0} k_{1}}\left[1-\exp \left(-6 k_{0} t / \mu_{n} m\right)\right]^{-\frac{1}{2}}
$$

The flow rate into the drain is

$$
\begin{gathered}
q_{\sigma \rho(n)}=m \sqrt{\frac{k_{0} k_{1}}{2}}\left[1-\exp \left(-\frac{6 k_{1} t}{\mu_{n} m}\right)\right]^{-\frac{1}{2}} \\
Q_{\sigma \rho(n)}=m \sqrt{2 k_{0} k_{1}}\left[1-\exp \left(-\frac{6 k_{1} t}{\mu_{n} m}\right)\right]^{-\frac{1}{2}}
\end{gathered}
$$

According to formulas (24) and (29), it is possible to determine the flow rate of drainage water at a given point of time and to track how the flow rate characteristics change over time. The total discharge of drainage water into the drainage belt from the phosphogypsum and sand strata for the entire period of dehydration $t_{\text {deh }}$ is determined in the form of definite integrals:

$$
Q_{\sigma \rho}=\int_{0}^{t_{d e h}} Q_{\sigma \rho(f)}(t) d t+\int_{0}^{t_{d e h}} Q_{\sigma \rho(n)}(t) d t
$$


where $t_{\text {deh }}$ is determined by the formula (20).

Multiplying the value of $\mathrm{Q}_{\sigma \rho}$ by the number of years, we find the total flow rate of the system consisting, for example, of 4, 7, I2, etc. lines of belt drains.

The total amount of free liquid required to remove from the sludge layer with the capacity $Z_{1}$ and the water loss of phosphogypsum $\mu_{\mathrm{f}}$ is determined from the ratio

$$
V_{C B}=S_{i} \cdot \mu_{p h} \cdot z_{1}
$$

To determine the duration of drainage (dehydration) of a given thickness of phosphogypsum, one should proceed from the ratio

$$
t_{o s}=\frac{V_{C B}}{n Q_{m p}}
$$

From this ratio, the optimal number of belt drains of the drainage system is selected. If the belt drain is made in the form of a banquette with a filtration coefficient $U$, a crosssectional area $\mathrm{F}$, a length $\mathrm{L}$, with a gradient $I$ and a site slope $i$, it is able to drain the following amount of liquid

$$
Q_{l}=F U(I+i), I_{a y}=h_{0}+\frac{z_{1}}{L}, I_{t o t}=\frac{z_{0}}{L},
$$

and the flow rate from the outlets is

$$
Q_{B}=K_{1} L_{1} m_{0}
$$

where $L_{1}$ and $m_{0}$ are the length and width of the banquette with outlets, respectively.

The flow rates into the drain for the periods' $t_{a v}$ and $t_{\text {tot }}$ are, respectively, $I_{o s}=\frac{z_{0}}{L}$

$$
Q_{a y(б)}=t_{a y} Q_{l} \quad ; \quad Q_{t o t(t)}=t_{t o t} Q_{l} \quad ; \quad Q_{\mathrm{B}(t o t)}=t_{t o t} Q_{\mathrm{B}}
$$

Then

$$
t_{o s}=\frac{V_{\mathrm{CB}}-t_{t o t}\left(Q_{l}+Q_{\mathrm{B}}\right)}{Q_{l}+Q_{\mathrm{B}}}
$$

Let the sludge collector cell be built up according to the internal scheme.

The mode of filling reservoirs bounded by secondary (tiered) dams provides for the formation of a pond of clarified water with a depth of $\mathrm{H}_{0}$ and an overflow of a sludge layer with a thickness of $Z_{1}=h-1.0(\mathrm{~m})$ (where $\mathrm{h}$ is the height of the dam) in the presence of a clarified water spillway.

For each tank, embanked with a dam of the $i$-th tier, the area of an equal-sized parallelepiped of a given height is determined. The sides of the tank base in the form of a truncated pyramid are determined based on the dam's height and the angles of its slopes.

The parameters of the filling, draw-off, and draining of tanks bounded by dams of the 2nd, 3rd, etc. tiers to the set mark are determined similarly. 


\section{Results and Discussion}

To illustrate the developed calculation method, we performed balance calculations for a sludge collector built up from phosphogypsum according to an internal scheme.

We assume the following values: the thickness of the sludge layer $Z_{1}=5.5 \mathrm{~m}$, the filtration coefficient of phosphogypsum and sand $\mathrm{K}_{1}=0.085 \mathrm{~m} /$ day, $\mathrm{K}_{0}=3 \mathrm{~m} /$ day, water depth in the pond $\mathrm{H}_{0}=0.5 \mathrm{~m}$, phosphogypsum porosity $\mathrm{n}_{1}=0.5$, fluid loss coefficients of phosphogypsum $\mu_{\mathrm{ph}}=0.04$, of sand $\mu_{\mathrm{s}}=0.15$, evaporation modulus $\varepsilon_{\mathrm{ev}}=0.0013 \mathrm{~m}^{3} /$ day, precipitation $\varepsilon_{\mathrm{pr}}=0.0007 \mathrm{~m}^{3} /$ day, specific pulp consumption per cell at the initial time of operation $\mathrm{q}_{2}=0.188 \mathrm{~m}^{3} /$ day; it is assumed that the flush is conducted by turns to a quarter of the cell.

Calculations are performed in the following sequence.

From formula (5), we determine the duration of the gradual draw-off of the pond. The calculation was conducted for a drier period, which is more favorable for drainage. For example, the duration of the complete draw-off of the pond is

$$
t_{a y}=\frac{5.5}{0.085} \ln \frac{0.5+5.584}{5.584}=5.545 \text { day }
$$

Let us determine by relations (9) and (11) the change in the radius of influence of the drain $\ell_{f}$ and the value of the flow rate entering the drain from the layer of phosphogypsum $Q_{d r(p h)}$ and by relations (13) and (15) from the sand layer $\ell_{n}, Q_{d r(p h)}$ as the clarified water pond is drawn-off. The total discharge into the drain $Q_{d r}$ is represented as the sum $Q_{d r(p h)}+$ $Q_{d r(p h)}$ multiplied by the number of belts.

Table 1. Pond draw-off parameters

\begin{tabular}{|c|c|c|c|c|c|c|c|c|c|c|}
\hline $\begin{array}{c}h_{0}, \\
m\end{array}$ & t. day & $\begin{array}{c}q_{f} m / d \\
a y\end{array}$ & $\ell_{f} \cdot m$ & $\begin{array}{c}Q_{\text {dr }(p h) .} \\
m^{3} / \text { day }\end{array}$ & $\ell_{n} \cdot m$ & $\begin{array}{c}Q_{\sigma p(n) .} \\
m^{3} / \text { day }\end{array}$ & $\begin{array}{c}Q^{2} \\
m^{3} / \text { day }\end{array}$ & $\begin{array}{c}4 Q_{\sigma p} . \\
m^{3} / \text { day }\end{array}$ & $\begin{array}{c}7 Q_{\sigma .} \\
m^{3} / \text { day }\end{array}$ & $\begin{array}{c}12 Q_{\sigma p} \\
m^{3} / \text { day }\end{array}$ \\
\hline 0.4 & 1.145 & 0.0912 & 3.61 & 399 & 1.217 & 124 & 523 & 2094 & 3661 & 6276 \\
\hline 0.3 & 1.278 & 0.0896 & 3.78 & 381 & 1.228 & 123 & 504 & 2016 & 3528 & 6048 \\
\hline 0.4 & 3.384 & 0.0881 & 3.82 & 377 & 1.238 & 122 & 499 & 1996 & 3493 & 5988 \\
\hline 0.1 & 4.478 & 0.0865 & 3.85 & 374 & 1.25 & 121 & 495 & 1980 & 3465 & 5940 \\
\hline 0 & 5.545 & 0.085 & 3.89 & 370 & 1.26 & 120 & 490 & 1960 & 3430 & 5880 \\
\hline
\end{tabular}

Based on formulas (11), (15) and (30), we estimate the total flow rate entering the drain for the period of pond draw-off (5.545 days), and assume that $q_{f}=\kappa_{1}$ and, due to their smallness, we ignore the terms $\exp \left(-\frac{6 \vartheta t}{\mu_{f z_{0}}}\right), \exp \left(-\frac{6 \vartheta t}{\mu_{n} m}\right)$

$$
Q_{d r}=\left(z_{1} k_{1} \sqrt{2}+m \sqrt{2 k_{1} k_{0}}\right) L \int_{0}^{5,545} d t=1807 \mathrm{~m}^{3} / d a y
$$

During the operation of 4 belts, the flow rate is $4 Q_{\mathrm{dr}}=5421 \mathrm{~m}^{3} /$ day, of 7 belts $\mathrm{Q}_{\mathrm{dr}}=$ $10842 \mathrm{~m}^{3} /$ day, of 12 belts $\mathrm{Q}_{\mathrm{dr}}=19877 \mathrm{~m}^{3} /$ day.

If the drainage system consists of pipe drains, then in the calculations of the accumulation period of the reservoir cell, it was obtained that the flow rate of such a drain is $\mathrm{Q}_{\text {pipe }}=485.5 \mathrm{~m}^{3} /$ day; $4 \mathrm{Q}_{\text {pipe }}=1942 \mathrm{~m}^{3} /$ dayt; $7 \mathrm{Q}_{\text {pipe }}=3398 \mathrm{~m}^{3} /$ day; $12 \mathrm{Q}_{\text {pipe }}=5826 \mathrm{~m}^{3} /$ day; comparing these flow rate characteristics with the data given in Table 1, we see that all the filtered water is drawn-off by pipe drains. 
The data characterizing the throughput of drainage belts made in the form of a banquette of two layers of filter material are presented in Table 2. They are calculated according to the relation (33)

Table 2. Parameters of belt drains in the form of a banquette during the pond draw-off period

\begin{tabular}{|c|c|c|c|c|c|c|}
\hline$h_{0}, m$ & $t$, day & $I+i$ & $\begin{array}{c}Q_{l,} \\
m^{3} / \text { day }\end{array}$ & $\begin{array}{c}4 Q_{l,} \\
m^{3} / \text { day }\end{array}$ & $\begin{array}{c}7 Q_{l,} \\
m^{3} / \text { day }\end{array}$ & $\begin{array}{c}12 Q_{l,} \\
m^{3} / \text { day }\end{array}$ \\
\hline 0.4 & 1.145 & 0.0117 & 27.6 & 110 & 193 & 331 \\
\hline 0.3 & 2.278 & 0.0115 & 27.2 & 109 & 190 & 326 \\
\hline 0.2 & 3.384 & 0.0114 & 26.8 & 107 & 188 & 322 \\
\hline 0.1 & 4.478 & 0.0112 & 26.4 & 106 & 185 & 317 \\
\hline 0 & 5.545 & 0.011 & 26.2 & 105 & 183 & 314 \\
\hline
\end{tabular}

After the draw-off of the pond, the flush of another $0.5 \mathrm{~m}$ of phosphogypsum should be done without forming a pond to the full depth. The height of the primary dam is $7 \mathrm{~m} ; 0.5 \mathrm{~m}$ is a protective layer of sand, 0.5 - is the pond depth and $5.5 \mathrm{~m}$ is the thickness of the flushed sludge. The remaining $0.5 \mathrm{~m}$ is required to prevent overflow of the dam. Thus, after an additional flush, the thickness of the phosphogypsum layer is $6 \mathrm{~m}$.

Calculation of dehydration of the tank, embanked by the primary dam.

Let us find the duration of dehydration of the phosphogypsum strata according to the formula (20) $\mathrm{t}_{\mathrm{tot}}=2.82$ days.

Using the same formula, we determine the duration of the layer-by-layer dehydration of the phosphogypsum stratum every $1.0 \mathrm{~m}$, and the change in the radius of influence of the drain in the phosphogypsum stratum $\ell_{f}$; the drain flow rate $Q_{d r}(f)$ is determined by formulas (22) and (24), and $\ell_{n}, Q_{d r(n)}$ are determined by formulas (27) and (29). The parameters obtained are summarized in Table 3, where $\mathrm{Q}_{\mathrm{dr}}$ is the sum of $Q_{d r(p h)}$ and $Q_{d r(p h)}$

Through the outlets located in the dam banquette, the drawn-off flow rate is

$$
\mathrm{Q}_{\mathrm{B}}=\mathrm{F} \cdot \mathrm{K}_{1}=620 \mathrm{~m} \cdot 1.9 \mathrm{~m} \cdot 0.085=100.1 \mathrm{~m}^{3} / \text { day }
$$

Table 3. Drainage parameters of the phosphogypsum and sand layer

\begin{tabular}{|c|c|c|c|c|c|c|c|c|}
\hline$h_{0}, m$ & $t$. day & $\ell_{f} \cdot m$ & $\begin{array}{c}Q_{d r}(p h) . \\
m^{3} / \text { day }\end{array}$ & $\ell_{n} \cdot \mathrm{m}$ & $\begin{array}{c}Q_{\text {dr }(n) .} \\
m^{3} / \text { day }\end{array}$ & $\begin{array}{c}4 Q_{d r .} \\
m^{3} / \text { day }\end{array}$ & $\begin{array}{c}7 Q_{d .} \\
m^{3} / \text { day }\end{array}$ & $\begin{array}{c}12 Q_{d r .} \\
m^{3} / \text { day }\end{array}$ \\
\hline 1.0 & 0.471 & 1.23 & 39 & 2.91 & 52 & 364 & 637 & 1092 \\
\hline 2.0 & 0.942 & 2.45 & 41 & 4.12 & 37 & 312 & 546 & 935 \\
\hline 3.0 & 1.413 & 3.68 & 117 & 5.04 & 30 & 588 & 1029 & 1754 \\
\hline 4.0 & 1.884 & 4.9 & 156 & 5.82 & 25 & 724 & 1267 & 2172 \\
\hline 5.0 & 2.355 & 6.13 & 194 & 6.50 & 23 & 868 & 1519 & 2604 \\
\hline 6.0 & 2.824 & 7.04 & 224 & 6.98 & 21 & 980 & 1715 & 2940 \\
\hline
\end{tabular}

The total flow rate of drainage water filtered from the layer of phosphogypsum and sand for the period of dehydration is determined by formulas (24) (26) and (30); in (26) $\exp \left(-\frac{6 \vartheta t}{\mu_{n} m}\right)$ is ignored due to its smallness; at $\mathrm{q}_{\mathrm{f}}=K_{1}$. $\mathrm{Q}_{\sigma p}=666 \mathrm{~m}^{3} /$ day. For 4 belts it is $1998 \mathrm{~m}^{3} /$ day, $7-3992 \mathrm{~m}^{3} /$ day, $12-7326 \mathrm{~m}^{3} /$ day. 
The total amount of free water in the thickness of phosphogypsum of $6.0 \mathrm{~m}$ and the area of $\mathrm{S}_{2}=399087 \mathrm{~m}_{2}$ is determined by the formula (31) $\mathrm{V}_{\text {св }}=399087 \cdot 0.04 \cdot 6=95781 \mathrm{~m}^{3}$

The duration of the discharge of the 2 nd cell of the sludge collector under the action of " $n$ " drainage belts is determined by the following ratio (32):

$$
\begin{gathered}
t_{o s(4)}=\frac{95781-1998}{980-100.1}=86,8 \text { day } ; \quad t_{o s(7)}=\frac{95781-3996}{1715-100.1}=50.6 \text { day } ; \\
t_{o s(12)}=\frac{95781-7326}{2940-100.1}=29.1 \text { day }
\end{gathered}
$$

From the results obtained, the most optimal value is $\mathrm{t}_{\mathrm{os}}$ with 7 drainage pipes. For a belt drain made in the form of a banquette from filtering material, the drainage water flow rate during the drainage period is determined by the dependencies (20) and (33) $Q_{l}=45 \mathrm{~m}^{3}$; $4 Q_{l}=135 \mathrm{~m}^{3}, 7 Q_{l}=270 \mathrm{M}^{3}, \quad 12 Q_{l}=4945 \mathrm{~m}^{3}$.

By relation (32), we have

$$
\begin{aligned}
& t_{\mathrm{os}(4)}=\frac{95781-135}{105+100.1}=466 \text { day; } \quad t_{\mathrm{os}(7)}=\frac{95781-270}{183+100.1}=336 \mathrm{day} ; \\
& t_{\mathrm{os}(12)}=\frac{95781-495}{314+100.1}=230 \mathrm{day} ;
\end{aligned}
$$

Calculations for building up secondary (tiered) dams.

Dam of the 1st tier. We will proceed from the assumption that an internal scheme does the embankment of tiered dams. For the construction of the first tier of the dam, $2.5 \mathrm{~m}$ high and with 1: 2.5 slope ratio, $94,442 \mathrm{~m}^{3}$ is needed, which frees up an additional $0.24 \mathrm{~m}$ of the tank. Thus, at the next stage, $2.5 \mathrm{~m}-1 \mathrm{~m}+0.24 \mathrm{~m}=1.74 \mathrm{~m}$ should be flushed, of which $0.5 \mathrm{~m}$ is occupied by a pond and $0.5 \mathrm{~m}$ is left to prevent overflows over the crest of the dam.

With a specific flow rate $q_{1}{ }^{\prime}=0.157 \mathrm{~m} /$ day, the area of an equal-sized parallelepiped $S_{1}^{\prime \wedge^{\prime}}=403271 \mathrm{~m} 3$ and the created tank $V_{1}^{\prime}==1008177 \mathrm{~m}^{3}$, according to the dependence $z_{1}=\alpha q t$, we find the duration of filling the tank (or rather a quarter of it since it was assumed that the flushing is not done over the entire area at once)

$$
t_{\text {flush }}=\frac{1,74}{0.145 \cdot 0.187}=64.44 \text { day. }
$$

Using formula [12], we find the formation duration of a pond with a depth of $0.5 \mathrm{~m}$.

$$
t_{\text {pond }}=\frac{0,5}{0,0179}=27.93 \text { day }
$$

The total flow rate entering the drain from the layer of phosphogypsum and sand during the pond formation is determined by formulas [12] and (30)

$\mathrm{Q}_{\text {flush }}=4750 \mathrm{~m}^{3} /$ day.

During the period of sludge flushing of a given power while maintaining a constant level in the pond $\left(\mathrm{H}_{0}=\right.$ const $)$ 
the drainage rate is determined at

$$
\begin{gathered}
q_{f}=k_{1} \frac{H_{0}+z_{0}+\alpha q t}{z_{0}+\alpha q t} ; \\
Q_{H_{0}=0,5}=\frac{k_{1}^{2}}{\beta}(\alpha q)^{2} \int_{0}^{36.51} t d t+m L \sqrt{2 k_{0} k_{1}} \int_{0}^{36.51} \sqrt{\frac{H_{0}+z_{0}+\alpha q t}{z_{0}+\alpha q t}} d t= \\
=1244+7190=9154 \mathrm{~m}^{3} / \text { day }
\end{gathered}
$$

The duration of the pond draw-off is determined by the formula (5)

$$
t_{d r}=\frac{7.5}{0.085} \ln \left(1+\frac{0.5}{7.385}\right)=5.788 \text { day }
$$

The flow rate entering the drain from the layer of phosphogypsum and sand during this period is determined by formulas (11), (15), and (30)

$$
Q_{d r}=k_{1} z_{1} L \sqrt{2}+m L \sqrt{2 k_{0} k_{1}} \int_{0}^{5.62} d t=2837+674=3511 \mathrm{~m}^{3} / \text { day }
$$

To simplify, it is assumed that $\exp \left(-\frac{6 \vartheta t}{\mu_{n} m}\right)$ tends to zero and $\mathrm{q}_{\mathrm{f}}=\mathrm{K}_{1}$

$$
t_{t o t}=\frac{8.0 \cdot 0,04}{0,085}=3.765 \text { day }
$$

During this period, the volume of water filtered into the drain is determined by formulas (24), (26), and (30)

$$
Q_{d r}=1037 \mathrm{~m}^{3} / \text { day; } 4 Q_{d r}=3111 \mathrm{~m}^{3} / \text { day; } 7 Q_{d r}=6222 \mathrm{~m}^{3} / \text { day; } 12 Q_{d r}=11407 \mathrm{~m}^{3} / \text { day; }
$$

Then, according to formula (31), we find the amount of free liquid in the thickness of the sludge:

$$
\mathrm{V}_{\mathrm{cB}}=403271 \times 0,04 \times 1,74+399087 \times 0,04 \times 6=123849 \mathrm{~m}^{3}
$$

To remove such an amount of water with a system of 4, 7 and 12 pipe drains, the following time periods are required:

$$
t_{o s(4)}=\frac{123849}{4 \cdot 485.5}=63.9 \text { day; } t_{o s(7)}=36.4 \text { day; } t_{o s(12)}=21.3 \text { day }
$$

The most acceptable is the drainage system of 7 belts of pipe drains.

Using the same methods, the parameters of the sludge collector operation are calculated when building up another 3 tiers of secondary embankment dams to the mark of $14 \mathrm{~m}$. The calculation data are summarized in Table 4. 
Table 4. Storage parameters for the construction of tiered dams

\begin{tabular}{|c|c|c|c|c|c|c|c|c|c|c|c|c|c|c|}
\hline $\begin{array}{c}\text { Para } \\
\text { mete } \\
\text { rs }\end{array}$ & $\begin{array}{l}\mathrm{S}_{\mathrm{i}_{2}} \\
\mathrm{~m}^{2}\end{array}$ & $\begin{array}{l}V_{i} \\
m^{3}\end{array}$ & $\begin{array}{l}\mathrm{V}_{\partial} \\
\mathrm{m}^{3}\end{array}$ & $\begin{array}{l}\mathrm{q}_{\mathrm{i}} \\
\mathrm{m} / \mathrm{d} \\
\text { ay }\end{array}$ & $\begin{array}{c}t_{\text {flus }} \\
\text { h.da } \\
y\end{array}$ & $\begin{array}{c}\text { Qflush. } \\
\mathrm{m}^{3} / \mathrm{da} \\
\mathrm{y}\end{array}$ & $\begin{array}{c}\mathrm{T}_{\mathrm{po}} \\
\mathrm{nd} \\
\mathrm{da} \\
\mathrm{y}\end{array}$ & $\begin{array}{l}Q_{H_{0}=0,5} \\
\mathrm{~m}^{3} / \text { day }\end{array}$ & $\begin{array}{c}\mathrm{T}_{\mathrm{a}} \\
\mathrm{y} \\
\mathrm{da} \\
\mathrm{y}\end{array}$ & $\begin{array}{c}\mathrm{Q}_{\mathrm{ay}} \\
\dot{\mathrm{m}}^{3} \\
/ \mathrm{da} \\
\mathrm{y}\end{array}$ & $\begin{array}{l}T_{t} \\
\text { ot } \\
\text { da } \\
y\end{array}$ & $\begin{array}{c}\mathrm{Q}_{\text {to }} \\
\mathrm{t} \\
\mathrm{m}^{3} \\
/ \mathrm{da} \\
\mathrm{y}\end{array}$ & $\begin{array}{l}V_{\text {CB }} \\
\mathrm{m}^{3}\end{array}$ & $\begin{array}{c}T_{\text {tott }} \\
\text { 7).da } \\
y\end{array}$ \\
\hline $\begin{array}{l}1-\mathrm{st} \\
\text { tier }\end{array}$ & $\begin{array}{l}40 \\
32 \\
71 \\
\end{array}$ & $\begin{array}{c}100 \\
817 \\
7\end{array}$ & $\begin{array}{c}94 \\
44 \\
2 \\
\end{array}$ & $\begin{array}{l}0.1 \\
87\end{array}$ & $\begin{array}{l}257 \\
.76\end{array}$ & 4750 & $\begin{array}{c}11 \\
1.7 \\
2 \\
\end{array}$ & 9154 & $\begin{array}{l}5 . \\
62\end{array}$ & $\begin{array}{l}35 \\
11\end{array}$ & $\begin{array}{c}3 . \\
76 \\
5\end{array}$ & $\begin{array}{l}10 \\
37\end{array}$ & $\begin{array}{l}12 \\
38 \\
49\end{array}$ & $\begin{array}{l}18, \\
22\end{array}$ \\
\hline $\begin{array}{c}2-n d \\
\text { tier }\end{array}$ & $\begin{array}{l}36 \\
83 \\
91\end{array}$ & $\begin{array}{l}920 \\
977\end{array}$ & $\begin{array}{c}89 \\
39 \\
0\end{array}$ & 0.2 & $\begin{array}{r}237 \\
.24\end{array}$ & 4123 & $\begin{array}{l}90 . \\
92\end{array}$ & 9080 & $\begin{array}{c}5 . \\
64 \\
4\end{array}$ & $\begin{array}{l}42 \\
86\end{array}$ & $\begin{array}{l}4 . \\
47\end{array}$ & $\begin{array}{l}13 \\
61\end{array}$ & $\begin{array}{l}14 \\
91 \\
94\end{array}$ & $\begin{array}{l}21, \\
95\end{array}$ \\
\hline $\begin{array}{l}\text { 3-rd } \\
\text { tier }\end{array}$ & $\begin{array}{l}33 \\
54 \\
15\end{array}$ & $\begin{array}{l}838 \\
537\end{array}$ & $\begin{array}{c}85 \\
68 \\
7\end{array}$ & $\begin{array}{l}0.2 \\
25\end{array}$ & $\begin{array}{l}213 \\
.48\end{array}$ & 3057 & $\begin{array}{l}66 . \\
88\end{array}$ & 8739 & $\begin{array}{c}5 . \\
66 \\
9\end{array}$ & $\begin{array}{l}50 \\
68\end{array}$ & $\begin{array}{c}5 . \\
41 \\
2\end{array}$ & $\begin{array}{l}18 \\
59\end{array}$ & $\begin{array}{l}17 \\
22 \\
71\end{array}$ & $\begin{array}{l}25, \\
34\end{array}$ \\
\hline $\begin{array}{l}\text { 4-th } \\
\text { tier }\end{array}$ & $\begin{array}{l}30 \\
33 \\
16\end{array}$ & $\begin{array}{l}758 \\
290\end{array}$ & $\begin{array}{c}81 \\
98 \\
0\end{array}$ & $\begin{array}{l}0.2 \\
48\end{array}$ & $\begin{array}{l}192 \\
.24\end{array}$ & 2463 & $\begin{array}{l}45 . \\
36\end{array}$ & 8419 & $\begin{array}{c}5 . \\
68 \\
6\end{array}$ & $\begin{array}{l}58 \\
48\end{array}$ & $\begin{array}{c}6 . \\
35 \\
3\end{array}$ & $\begin{array}{l}24 \\
29\end{array}$ & $\begin{array}{l}19 \\
32 \\
60\end{array}$ & $\begin{array}{c}28, \\
43\end{array}$ \\
\hline
\end{tabular}

Table 5. The ratio of drainage water and wastewater

\begin{tabular}{|c|c|c|c|c|c|c|c|}
\hline $\mathrm{q}_{\mathrm{i}} \cdot \mathrm{m} /$ day & $\mathrm{t}_{\mathrm{i}}$.day & $\mathrm{Z}_{0} \cdot \mathrm{m}$ & $\mathrm{q}_{\mathrm{f} .} \mathrm{m} / \mathrm{day}$ & $\mathrm{q}_{0} \cdot \mathrm{m} /$ day & $\mathrm{Q}_{0} \cdot \mathrm{m}^{3} /$ day & $7 Q_{d r}$ & $\begin{array}{c}7 Q_{d r} / \mathrm{Q}_{0} \\
\cdot 100 \%\end{array}$ \\
\hline 0.187 & 36.51 & 7.5 & 0.09 & 0.0706 & 1039474 & 64078 & 6.16 \\
\hline 0.200 & 36.58 & 9.5 & 0.0894 & 0.0826 & 1113096 & 63560 & 5.71 \\
\hline 0.225 & 36.65 & 11.5 & 0.0883 & 0.1028 & 1266175 & 61173 & 4.83 \\
\hline 0.248 & 36.72 & 13.5 & 0.0879 & 0.1248 & 1389993 & 58933 & 4.24 \\
\hline
\end{tabular}

As follows from the data given in Table 4, the build-up of the storage tank allows increasing the service life of the sludge accumulator by 900,72 cyт ( $\sum t_{f u s h}$ for all tiers), which is about 3 years (2.9) for the period in which the tank, bounded by the primary dam is filled. As the accumulator is building-up, the storage facilities $\left(V_{i}^{\prime}\right)$, embanked up by tiered dams, decrease because there is an internal build-up, the period of filling the tanks (tp) is reduced, the duration of the pond formation $\left(t_{\text {pond }}\right)$ decreases. The drainage system of 7 belts of pipe drains removes free water from the phosphogypsum strata within a reasonable time interval ( $\mathrm{t}_{\mathrm{os}}=18 \div 28$ days).

Let us calculate what part of the circulating water is the drainage water during the period of discharge, i.e. during the period of maintaining a constant water depth in the pond $\left(\mathrm{H}_{0}=\right.$ const $\left.=0.5\right)$, for all tiers. These calculations are presented in Table 5. We use the formula in which the value of the specific flow rate of the filtration flow $q_{\phi}$ is determined by the following relation

$$
q_{f}=k_{1} \frac{H_{0}+z_{0}+\alpha q t}{z_{0}+\alpha q t}
$$

Multiplying the value of the specific discharge of waste water by the corresponding value of the area $S_{i}$ and the duration of the period $t_{i}$, we determine the total amount of waste water for this period - $Q_{0}$. We compare this value with the amount of drainage water with 7 belts of drainage, i.e. $7 Q_{\left(H_{0}=c o n s t\right)}$, and express this relation in a percent. As follows from the data given in Table 5, as the tiers grow, the total amount of waste water increases, the amount of drainage water decreases, and, accordingly, their percentage decreases. 


\section{Conclusions}

Filtration processes in sludge collectors were investigated, and a method was developed for calculating the filtration of phosphogypsum with an impermeable screen (made of polymer film, asphalt-polymer concrete, etc.), above the screen drainage system and the primary dam with slopes protected by a watertight diaphragm made of film at the second period.

A period of cell preparation precedes the second build-up period, namely: the pond draw-off and drainage of the cell to a moisture content suitable for filling-in the dams and normal operation of the mechanisms used in the dam construction. According to the developed methods, it is possible to determine the parameters of the draw-off and drainage of the cell by the primary dam and the embankment dams of the $2 \mathrm{nd}$, 3rd, etc. tiers.

\section{References}

1. Kondratyev, L.I., Manushin, A.A., Melnikov, I.T., Surov, A.I. Combined technology of storage of tailings for the production of mineral fertilizers. Vestnik MGTU named after G. Nosov - 2. pp.21, (2010)

2. Kutepova, N.A., Kutepov, Yu.I., Kudashov, E.S., Daniliev, S.M. Strength of phosphogypsum mixed with nepheline slime in construction of embankments of gypsum ponds. Mining Informational and Analytical BulletinVolume (10). pp.67-78, (2020)

3. Sultanov, T., Fayziev, Kh., Toshmatov, E., Zokirov, I. Stability of dam slopes of phosphogypsum sludge collectors. FORM-2020 IOP Conf. Series: Materials Science and Engineering. 2020. 869 (2020). Pp. 1-10. DOI:10.1088/1757899X/869/7/072031.

4. Sakharova, A.A., Sidyakin, P.A., Shchitov, D.M., Nesterchuk, A.V. Recycling of waste to secondary raw materials as a way to increase environmental safety of production. IOP Conference Series: Materials Science and Engineering. (2020). 913(5).

5. Zhang, J., Yu, F. Research on dynamic response of phosphogypsum tailing ponds under seismic load. 2011 2nd International Conference on Mechanic Automation and Control Engineering. pp.3354-3358, (2011)

6. Zhang, C., Yu, -K.J., Yang, C.-H., Chen, J.-W. Stability analysis of high phosphogypsum dam. Yantu Lixue / Rock and Soil Mechanics. 27. pp.113-117. (2006)

7. Solskiy, S.V., Stephanishchin, D.V., Finagenov, O.M., Shulman, S.G. Reliability of storage facilities for industrial and household waste. SPB Publishing House of JSC "VNIIG named after B.E. Vedeneev". pp.300, (2006)

8. Mironenko, V.A. Dynamics of groundwater. Textbook. - 4th ed., - M.: Publishing house of MGGU. pp.519, (2005)

9. Ivanitskiy, V.V. et al. Phosphogypsum and its use. Chemistry. pp.224, (1990)

10. Vasiliev, S.V., Verigin, N.N., et al. Methods of filtration calculations of irrigation and drainage systems. Kolos. pp.440, (1970)

11. Nedriga, V.P. Engineering protection of groundwater from industrial wastewater pollution. Moscow: Stroyizdat. pp.96, (1976)

12. Fayziev, Kh., Sultanov, T., Toshmatov, E., Numonov, A. Filtration and operational parameters determination of phosphogypsum sludge storage. IOP Conf. Series: Materials Science and Engineering. 2021. 1030 01214. Pp. 1-10. DOI:10.1088/1757899X/1030/1/012143.

13. Mirsaidov, M.M., Sultanov, T.Z., Rumi, D.F. An assessment of dynamic behavior of the system "structure - Foundation" with account of wave removal of energy. 
Magazine of Civil Engineering. 2013. 39(4). Pp. 94-105. DOI:10.5862/MCE.39.10.

14. Mirsaidov, M.M., Toshmatov, E.S. Spatial stress state and dynamic characteristics of earth dams. Magazine of Civil Engineering. 2019. 89(5). Pp. 3-15. DOI:10.18720/MCE.89.1.

15. Mirsaidov, M. An account of the foundation in assessment of earth structure dynamics. E3S Web of Conferences. 97,04015. 2019. DOI:10.1051/e3sconf/20199704015.

16. Sultanov, T.Z., Khodzhaev, D.A., Mirsaidov, M.M. The assessment of dynamic behavior of heterogeneous systems taking into account non-linear viscoelastic properties of soil. Magazine of Civil Engineering. 2014. 45(1). Pp. 80-89+117-118. DOI:10.5862/MCE.45.9.

17. Ismayilov,K., Mavlonov,T, Yuldoshev,B., Toshev, S. Compressed rectangular plates stability beyond the elastic limit. Materials Science and Engineering. 2020. 883. Pp. 1-8. DOI:10.1088/1757-899X/883/1/012199.

18. Ismayilov, K. Critical stresses and deformations in a hinged-supported Rectangular plate beyond the elastic limi. European journal Of technical and Natural sciences. 3. pp.32-36, (2018)

19. Vasiliev, S.V.V.N.N. et al. Filtration from reservoirs and ponds. Kolos. pp.302, (1976)

20. Yangiev, A., Gapparov, F., Adjimuratov, D. Filtration process in earth fill dam body and its chemical effect on piezometers. 2nd International Scientific Conference on Construction the Formation of Living Environment, FORM (2019)

21. Shaazizov, F., Shukurov, D. Physical modeling of the filtration process through the dam base. IOP Conference Series: Materials Science and Engineering. (2020). 869(7).

22. Bazarov, D., Norkulov, B., Vokhidov, O., Uljaev, F., Ishankulov, Z. Two-dimensional flow movement in the area of protective regulatory structures. IOP Conference Series: Materials Science and Engineering. (2020). 890(1).

23. Bakiev, M., Kaxxarov, U., Jakhonov, A., Matkarimov, O. Kinematic characteristics of the flow, in the compression region, with bilateral symmetric restriction by floodplain dams. IOP Conference Series: Materials Science and Engineering. (2020). 869(7).

24. Sultanov, K.S., Vatin, N.I. Wave Theory of Seismic Resistance of Underground Pipelines. Appl. Sci. 2021. 11(1797). DOI:https://doi.org/ 10.3390/app11041797.

25. Sultanov, K.S., Khusanov, B.E., Rikhsieva, B.B. Mathematical model of underground structure-soil interaction. IOP Conference Series: Materials Science and Engineering. (2020). 962(3). 